\title{
RETRACTED ARTICLE: Dépistage du cancer épidermoïde de l'osophage par chez les sujets à risque élevé de cancer endoscopie
}

RETRACTED ARTICLE: Endoscopic screening of esophageal squamous cell carcinoma in high risk patients

\author{
E. Vaillant $\cdot$ D. Heresbach $\cdot$ A. Calazel $\cdot$ T. Ponchon \\ C Springer-Verlag France 2009
}

A preliminary version of article " Dépistage du cancer épidermoïde de l'œsophage par endoscopie chez les sujets à risque élevé de cancer ", was published online in error in February 2010. The revised and correct version of the article "Dépistage du cancer épidermoüde de l'osophage par endoscopie chez les sujets à risque élevé de cancer " was published in the journal Acta Endoscopica in June 2010 (Volume 40, Issue 3, pp 149-156, 10.1007/s10190-009-0001-7).

The Publisher has therefore decided to retract the preliminary version of the article.

E. Vaillant $(\bowtie)$

Réseau de cancérologie Oncomel, 104, rue Jemmapes,

F-59800 Lille, France

e-mail : vaillant-e@orange.fr

D. Heresbach

Service des maladies de l'appareil digestif,

CHU Pontchaillou, F-35033 Rennes, France

A. Calazel · T. Ponchon

Commission santé publique de la SFED,

50, boulevard de Port-Royal, F-75005 Paris, France 